\title{
LABOR-MARKET COMPETITION AND INDIVIDUAL PREFERENCES OVER IMMIGRATION POLICY
}

\author{
Kenneth F. Scheve \\ Matthew J. Slaughter
}

Working Paper 6946

http://www.nber.org/papers/w6946

\section{NATIONAL BUREAU OF ECONOMIC RESEARCH 1050 Massachusetts Avenue \\ Cambridge, MA 02138 \\ February 1999}

For helpful comments, we thank Jim Alt, Patty Anderson, Danny Blanchflower, Irene Bloemraad, George Borjas, Lawrence Broz, Alan Kessler, Dave Richardson, and seminar participants at Harvard University. For financial support Scheve thanks the Harvard-MIT McArthur Program on Transnational Security and the Weatherhead Center for International Affairs; Slaughter thanks the Russell Sage Foundation. The views expressed here are those of the author and do not reflect those of the National Bureau of Economic Research.

(1) 1999 by Kenneth F. Scheve and Matthew J. Slaughter. All rights reserved. Short sections of text, not to exceed two paragraphs, may be quoted without explicit permission provided that full credit, including (1) notice, is given to the source. 
Labor-Market Competition and Individual

Preferences Over Immigration Policy

Kenneth F. Scheve and Matthew J. Slaughter

NBER Working Paper No. 6946

February 1999

JEL No. F22, J31, J61

\section{ABSTRACT}

This paper uses an individual-level data set to analyze the determinants of individual preferences over immigration policy in the United States. In particular, we test for a link from individual skill levels to stated immigration-policy preferences. Different economic models make contrasting predictions about the nature of this link. We have two main empirical results. First, lessskilled workers are significantly more likely to prefer limiting immigrant inflows into the United States. The result is robust to several different econometric specifications which account for determinants of policy preferences other than skills. Our finding suggests that over time horizons relevant to individuals when evaluating immigration policy, individuals thank that the U.S. economy absorbs immigrant inflows at least partly by changing wages. These preferences are consistent with a "multi-cone" Heckscher Ohlin trade model and with a factor-proportions-analysis labor model. Second, we find no evidence that less-skilled workers in high-immigration communities are especially anti-immigrationist. If anything, our evidence suggests attenuation of the skillspreferences correlation in high-immigration communities. These preferences are inconsistent with an area-analysis labor model.

Kenneth F. Scheve

Department of Government

Harvard University

M-42 Littauer Center

Cambridge, MA 02138

kscheve@latte.harvard.edu
Matthew J. Slaughter

Department of Economics

Dartmouth College

309 Rockefeller Hall

Hanover, NH 03755

and NBER

slaughter@dartmouth.edu 


\section{Introduction}

Individual preferences over immigration policy are an essential input into any complete model of immigration policymaking. To understand both the policies implemented and the accompanying political conflict, we need to know who supports more or less-restrictionist policies and why. Preferences surely depend on a host of considerations including political ideology, ethnic and racial identity, and expectations about the economic impact of new immigrants. Among economic considerations, the anticipated effect of immigration on wages is likely to play a key role, as current factor income is a major determinant of individual economic welfare. Because current factor income depends primarily on individual skill levels, there may be a significant link from skills to wages to immigration-policy preferences.

Different economic models, however, make contrasting predictions about the nature of this link. In the "multi-cone" Heckscher-Ohlin model of international trade, immigrants sometimes have no impact on native wages. "Factor-proportions analysis," a framework often used by labor economists researching immigration, predicts that immigrants pressure the wages of similarlyskilled natives nationwide. "Area analysis," an alternative framework in the labor literature, predicts that immigrants pressure the wages of similarly-skilled natives who reside in gateway communities where immigrants settle. In short, there is theoretical uncertainty about the wagesmediated link between skills and preferences in addition to the empirical uncertainty regarding whether individuals consider labor-market competition when evaluating immigration policy. ${ }^{1}$

In this paper we provide new evidence on the determinants of individual immigration-policy preferences and on what these preferences imply about how economies absorb immigrants. We use a direct measure of these preferences obtained from the 1992 National Election Studies (NES) survey (Miller 1993), an extensive survey of current political opinions based on an individual-level stratified random sample of the U.S. population. Our direct measure is responses of U.S. citizens to a question asking about the number of immigrants U.S. policy should permit. Building on the NES survey, we construct an individual-level data set identifying both stated immigration-policy

\footnotetext{
${ }^{1}$ The terms "area analysis" and "factor-proportions analysis" we borrow from Borjas, et al (1996).
} 
preferences and potential immigration exposure through several channels. We then evaluate how these preferences vary with individual characteristics that alternative theories predict might matter.

We have two main empirical results. First, less-skilled workers are significantly more likely to prefer limiting immigrant inflows into the United States. This result is robust to several different econometric specifications which account for determinants of policy preferences other than skills. Our finding suggests that over time horizons relevant to individuals when evaluating immigration policy, individuals think the U.S. economy absorbs immigrant inflows at least partly by changing wages. Further, they form policy opinions in accord with their interests as labor-force participants. These preferences are consistent with a multi-cone Heckscher Ohlin trade model and with a factor-proportions-analysis labor model. Second, we find no evidence that less-skilled workers in high-immigration communities are especially anti-immigrationist. If anything, our evidence suggests attenuation of the skills-preferences correlation in high-immigration communities. These preferences are inconsistent with an area-analysis labor model.

There are five additional sections to this paper. Section 2 relates our work to the politicaleconomy literature on immigration. Section 3 presents alternative economic models of immigration-policy preferences. The following section discusses the data and our model specifications. Section 5 presents the empirical results, while Section 6 concludes.

\section{The Political Economy of Immigration Policy}

Previous research on the determinants of immigration policy in receiving countries has emphasized the variation in immigration politics across countries and over time (Joppke 1998, Kessler 1998, Perotti 1998, Money 1997, Freeman 1992 and 1995). There is general agreement that systematic differences in policy outcomes across countries depend on varying political institutions, divergent national histories of settlement and colonialism, and the different effects of a changing international context. Moreover, it seems clear that even within countries the character of immigration politics changes over time. For example, a country's interest groups can dominate the policymaking process during some periods while in other periods partisan electoral competition is central. In contrast to this observed variation across time and space, very little research has 
focused on the distribution of individual preferences over immigration policy. Who supports free movement? Who advocates further restrictions? We contend that only once these questions about preferences have been answered adequately can a convincing account of cross-country and overtime variation in policymaking be constructed.

Accounts of individual preferences can usefully be divided into economic and non-economic determinants. Non-economic factors include individual beliefs about civil rights and expectations regarding the cultural impact of immigrants. The civil-rights dimension of immigration-policy preferences has both a non-discrimination aspect as well as a more straightforward free movement of persons element. Individual policy preferences are also likely to depend both on the degree to which individuals think immigrants change native culture and on the desirability of those changes.

Economic determinants are generally hypothesized to be a function of the aggregate costs and benefits of immigration, the fiscal impact on the public sector, and the impact of immigrants on native labor-market returns. This last consideration is arguably the most critical economic factor influencing individual policy preferences, and it is often the most controversial factor as well. Consequently, it is the main issue addressed in this paper. ${ }^{2}$

In previous work, Goldin (1994) and Timmer and Williamson (1996) present historical evidence on the potential impact of labor-market outcomes on immigration policy. Goldin (1994) finds that House Representatives in 1915 were more likely to vote in favor of a literacy test to restrict immigrant inflows the lower were wage increases from 1907 to 1915 in the Representatives' district cities. Goldin interprets this as indirect evidence that immigrants' pressure on native wages contributed to tighter immigration restrictions. Pooling five countries from 1860 to 1930, Timmer and Williamson (1996) find that more-restrictionist immigration policies were significantly correlated with lower unskilled wages relative to average per capita income. They

\footnotetext{
2 Borjas (1995) concludes that U.S. immigration's main economic impact is on the distribution of income, not on its aggregate level.
} 
interpret this correlation as evidence that countries with more unequal income distributions tended to restrict immigration to maintain the relative income position of the less-skilled. ${ }^{3}$

In contrast to the policy focus of Goldin (1994) and Timmer and Williamson (1996), Citrin, et al (1997) use individual-level survey data to study the immigration-policy preferences of a crosssection of U.S. citizens. Controlling for a wide range of factors that potentially shape preferences, they conclude "that personal economic circumstances play little role in opinion formation" (p. 858). Specifically, they find that labor-market competition does not influence preferences. Using information from a national poll, Espenshade and Hempstead (1996) find some mixed evidence that less-educated and lower-family-income individuals are more likely to support immigration restrictions. They interpret this evidence as suggesting that people care about immigration's labormarket impacts on wages, employment, and work conditions.

All these studies provide valuable information on the economic determinants of immigrationpolicy preferences and political behavior. However, our work improves upon them in at least three important ways.

First, our study uses a direct measure of individual immigration-policy preferences. Some studies cited above infer from observed political actions or policy outcomes something about immigration-policy preferences. These indirect preference measures face the important limitation of being endogenous outcomes of the interaction between immigration-policy (and possibly other, e.g., foreign-policy) preferences and domestic political institutions. Policy preferences and institutions together determine policy actions, so the mapping from preferences to actions and outcomes is not unambiguous. Scheve and Slaughter (1998) discuss this point further.

Second, our study draws heavily on the trade and labor-economics literature on immigration to test properly for the economic determinants of immigration preferences. We test three alternative models of how immigration affects the economic welfare of natives. In contrast, none of the related studies explicitly lays out any models of immigration. Instead, they all simply assume that

\footnotetext{
${ }^{3}$ Hanson and Spilimbergo (1998) analyze the impact of economic conditions in the United States and Mexico on a different aspect of immigration policy: border enforcement and apprehensions. They find that the Mexican (i.e., not U.S.) purchasing power of U.S. nominal wages is strongly correlated with border apprehensions of illegal Mexican immigrants.
} 
immigration hurts natives via lower wages, unemployment, and other adverse outcomes. Many important issues have not been explored, such as whether immigration preferences are systematically different in gateway communities.

Third, our study uses measures of individual economic exposure to immigration that follow closely from economic theory. This issue applies most strongly to Citrin, et al (1997) and Espenshade and Hempstead (1996). Empirical labor economists commonly measure skills via educational attainment or occupation classification; our empirical work below uses both these measures. ${ }^{4}$ In contrast, Citrin, et al (1997) interpret educational attainment as a "demographic variable" rather than an "economic factor." Although this choice has some justification in previous studies on the relationship between education and tolerance, we will demonstrate that education measures labor-market skills once other considerations such as gender and political ideology are controlled for. Citrin, et al (1997) measure skills with income and with eight dichotomous occupation variables. Only four of the eight cover working individuals, and these -- "white collar," "pink collar," "low threat blue collar," and "high threat blue collar" -- are never defined or justified with reference to economic theory or evidence. Espenshade and Hempstead (1996) use dichotomous variables for educational attainment and family -- not individual -- income, with all specifications using both types of variables. Overall, these earlier studies use questionable skill measures, and they do not report specifications with single measures only nor do they test the joint significance of all skill measures together. These uncertainties regarding measurement and specification suggest the need for further analysis.

\section{Economic Models of Immigration-Policy Preferences}

To make the connection between individual economic interests and immigration-policy preferences we focus on how immigration affects individual factor incomes. Differenteconomic models make contrasting predictions about the nature of the link from immigration to factor

\footnotetext{
${ }^{4}$ For example, in the recent research on the rising U.S. skill premium the two most commonly used measures of the skill premium have been the relative wage between college graduates and high-school graduates and the relative wage between non-production workers and production workers (in manufacturing only). See Katz and Murphy (1992) or Lawrence and Slaughter (1993), for example. Berman, et al (1994) document for the United States that employment trends for this jobclassification measure track quite closely employment trends measured by the white-collar/blue-collar job classification-which in turn closely reflects the college/high-school classification.
} 
incomes to policy preferences. In this section we briefly summarize three alternative models: the multi-cone Heckscher-Ohlin trade model, the factor-proportions-analysis model, and the areaanalysis model.

Across all three models we make two important assumptions. First, we assume that current factor income is a major determinant of people's economic well-being. Second, we assume that U.S. citizens think that current immigrant inflows increase the relative supply of less-skilled workers. As will be seen below, this assumption about the skill-mix-effects of immigrants is not explicitly stated in the NES question about immigration preferences. But this assumption clearly reflects the facts about U.S. immigration in recent decades. Borjas, et al $(1997$, p. 6) report that "on average, immigrants have fewer years of schooling than natives - a difference that has grown over the past two decades, as the mean years of schooling of the immigration population increased less rapidly than the mean years of schooling of natives. As a result, the immigrant contribution to the supply of skills has become increasingly concentrated in the lower educational categories." Thus, we are assuming NES respondents are generally aware of U.S. immigration composition. ${ }^{5}$

Given these two assumptions, we think that the economic determinants of an individual's immigration-policy preferences depend on how an immigration-induced shift in the U.S. relative endowment towards less-skilled workers affects that individual's factor income. To maintain focus on equilibrium wage determination, in all models we assume that wages are sufficiently flexible to ensure full employment. This allows us to abstract from unemployment, both equilibrium and frictional, though unemployment will be considered in our empirical work. To maintain focus on different skill groups, in all models we assume just two factors of production, skilled labor and unskilled labor. This keeps our analysis as simple as possible. ${ }^{6}$

\footnotetext{
${ }^{5}$ This skills gap between immigrants and natives does not address other interesting facts about the distribution of skills among immigrants. For example, Borjas, et al (1997. p. 7) show that the skill distribution of U.S. immigration has been somewhat bimodal at both the high-skill and low-skill ends of the distribution.

${ }^{6}$ In the political economy literature, some researchers analyze the theory of economic determinants of immigration-policy preferences. Benhabib (1996) considers a one-good model in which natives have different endowments of capital. Kessler (1998) focuses on how trade and immigration affect native factor returns in standard trade models. Bilal, et al (1998) consider the case of a three-factor, two-household, two-country world.
} 


\subsection{The Multi-Cone Heckscher-Ohlin Model}

The multi-cone Heckscher-Ohlin (HO) trade model usually makes two key assumptions. First, there is one national labor market for each factor. Thanks to sufficient mobility of natives (and immigrants upon arrival), there are no geographically segmented "local" labor markets. The second key assumption is there are more tradable products (i.e., sectors) than primary factors of production, with products differentiated by their factor intensities. Multiple products are essential for establishing many fundamental trade-theory results, such as comparative advantage.

With these assumptions, in equilibrium a country chooses (via the decentralized optimization of firms) the "output mix" that maximizes national income subject to the constraints of world product prices, national factor supplies, and national technology. This output mix consists of both which products actually get produced -- i.e., the country's "cone of diversification" -- and the quantities of production. In turn, this output mix helps determine the country's national factor prices. The general intuition is that each produced sector has a world price and some technology parameters that both help determine national wages. In the standard case where the country makes at least as many products as the number of primary factors, national wages are completely determined by the world prices and technology parameters of the produced sectors. Wages do not depend on national endowments or on the prices and technology of the non-produced sectors. ${ }^{7}$

Immigration's wage effects depend both on the initial product mix and on the size of the immigration shock. Consider the standard case where the initial output mix is sufficiently diversified that wages depend only on world prices and technology. In this case, "sufficiently small" shocks have no wage effects. The country completely absorbs immigrants by changing its output mix as predicted by the Rybczynski Theorem: the same products are produced, but output increases (decreases) in the unskill-intensive (skill-intensive) sectors. Wages do not change

\footnotetext{
${ }^{7}$ In the algebra of the Heckscher-Ohlin model, wages are determined by the set of "zero-profit conditions." Each zero-profit condition is an equation setting a sector's world price equal to its domestic average cost, which in turn depends on domestic production technology and domestic wages. Algebraically, wages are the unknown endogenous variables and prices and technology are the known exogenous variables. In the standard case there at least as many equations as unknowns, so these equations alone determine wages. National endowments do not matter; nor do prices and technology in the idle sectors (which do not have binding zero-profit conditions because the world price is less than domestic cost -- thus the national decision not to produce these sectors). In the alternative case with fewer produced sectors than primary factors, there are fewer equations than unknowns. Here, endowments matter because prices and technology are not sufficient to set wages.
} 
because the set of products does not change. This insensitivity of national wages to national factor supplies Leamer and Levinsohn (1995) call the Factor-Price-Insensitivity (FPI) Theorem. ${ }^{8}$

With "sufficiently large" immigration shocks, however, national wages do change. Large enough shocks lead the country to make a different set of products. Different products entail different world prices and technology parameters influencing national wages -- and thus different wages. Overall, a country absorbs large immigration shocks by changing both its output mix and its wages. In the literature on U.S. immigration, Hanson and Slaughter (1999) present evidence of immigration-related output-mix effects among U.S. states.

Figure 1 displays the national labor market for the case of an $\mathrm{HO}$ world with three products. The distinguishing feature is the shape of relative labor demand. It has two perfectly elastic portions, each of which corresponds to a range of endowments for which FPI holds. The national output mix varies along the demand schedule. A different set of two products is made on each elastic part; accordingly, different relative wages prevail on each elastic part. On the downwardsloping portions the country makes only one product. Along these portions output-mix changes are not possible, so immigrants must price themselves into employment by changing wages. Point $E_{o}$ designates the initial labor-market equilibrium, with relative labor supply $\mathrm{RS}_{\mathrm{o}}$ and relative wages $\left(\mathrm{w}_{\mathrm{s}} / \mathrm{w}_{\mathrm{u}}\right)_{\mathrm{o}}$. Two immigration shocks are shown. The "sufficiently small" immigration shock shifts $\mathrm{RS}_{\mathrm{o}}$ to RS'. Relative wages do not change, as immigrants trigger Rybczynski output-mix effects. The "sufficiently large" shock shifts $\mathrm{RS}_{\mathrm{o}}$ to RS". The country now produces a new set of products. As a result the unskilled wage falls relative to the skilled wage (to $\left(\mathrm{w}_{\mathrm{s}} / \mathrm{w}_{\mathrm{u}}\right)$ )"), and with fixed product prices this relative-wage decline will be a real-wage decline as well. ${ }^{9}$

\footnotetext{
${ }^{8}$ These two theorems follow closely from the Factor-Price-Equalization (FPE) Theorem, first demonstrated formally by Samuelson (1948). With additional assumptions about cross-country similarities (such as identical tastes and production technology), the FPE theorem predicts not only that national wages are determined by world prices and technology only but that national wage levels equal foreign wage levels. Also, note that factor-price insensitivity assumes that the country is sufficiently small in the world economy that changes in its relative-output mix do not change world product prices. If world prices do change than so, too, do domestic wages as predicted by the Stolper-Samuelson Theorem.

${ }^{9}$ Three detailed comments on Figure 1. First, the relative-supply schedule is vertical under the assumption that all workers are sufficiently willing to work that they price themselves into employment regardless of the going relative wage. If workers make some explicit labor-leisure trade-off then the relative-supply schedule slopes upward but is not perfectly vertical. Second, along the national demand schedule the country's output mix progresses according to sector factor intensities. The likely output mixes are as follows. Along the leftmost branch of RD the country makes only the most unskilled-labor-intensive product. Along the first flat it makes this product and the "middle" intensity product, switching to only the middle product along the middle downward-sloping branch. The country picks up the most skilled-laborintensive product as well along the second flat; finally, along the rightmost branch it makes only the skilled-labor-
} 
The HO model has different predictions about link between skills and immigration-policy preferences. If individuals think FPI holds then there should be no link from skills to preferences. In this case people evaluate immigration based on other considerations. If individuals think that immigration triggers both output-mix and wage effects then unskilled (skilled) workers nationwide should prefer policies which lower (raise) immigration inflows.

\subsection{The Factor-Proportions-Analysis Model}

Like the HO model, this model also assumes a national labor market. The fundamental difference between the two is this model assumes a single aggregate output sector. Under this assumption there can be no output-mix changes to help absorb immigrants. Accordingly, any immigration inflow affects national wages by the same logic described above. Lower relative wages for unskilled workers induces firms to hire relatively more of these workers. The greater the immigrant inflow, the greater the resultant wage changes. In the labor literature, studies using this framework include Borjas, et al $(1996,1997)$. These studies calculate immigration-induced shifts in national factor proportions and then infer the resulting national wage changes.

Figure 2 displays the national labor market for the factor-proportions-analysis world. Here the relative-labor-demand schedule slopes downward everywhere, with no infinitely-elastic portions where FPI holds. Initial relative labor supply is again given by the schedule $\mathrm{RS}_{\mathrm{o}}$, with initial equilibrium again at $\mathrm{E}_{\mathrm{o}}$ and $\left(\mathrm{w}_{\mathrm{s}} / \mathrm{w}_{\mathrm{u}}\right)_{\mathrm{o}}$. Immigration shifts the supply schedule back to RS', and the national skill premium rises to $\left(\mathrm{w}_{\mathrm{s}} / \mathrm{w}_{\mathrm{u}}\right)^{\prime}$. Again, for fixed product prices real wages change, too.

This model makes a single prediction about the link from skills to immigration-policy preferences: unskilled (skilled) workers nationwide should prefer policies to lower (raise) immigration inflows. This prediction can also come from the HO model without FPI. Accordingly, evidence of a link between skills and preferences is consistent with both models.

\subsection{The Area-Analysis Model}

Like the previous model, the area-analysis model also assumes a single output sector. The fundamental difference between the two is this model assumes distinct, geographically segmented

intensive product. Finally, note that underlying the downward-sloping portions of RD is the assumption of flexible production technologies with substitutability among factors. With Leontief technology these portions would be vertical. 
labor markets within a country. This assumption is likely untrue in the very long run, but it may be true over shorter time horizons thanks to frictions such as information and transportation costs that people (both natives and immigrants upon arrival) must incur to move. "Local" labor markets are usually defined by states or metropolitan areas (many of which cross state boundaries). Each local labor market has its own equilibrium wages determined by local supply and local demand.

If there is literally no mobility among local labor markets, immigrants' wage effects are concentrated entirely in the "gateway" communities where they arrive: immigration lowers (raises) wages for the unskilled (skilled). In contrast, in a national labor market immigrants' wage pressures spread beyond gateway communities. Natives can leave gateway communities when immigrants arrive; immigrants can move on to other communities; or natives can choose not to enter gateway communities as planned pre-immigration. In cases between these two extremes, immigrants affect wages everywhere but to a greater extent in gateway labor markets. The areastudies framework has guided a number of empirical studies of immigration. Studies such as Card (1990), Altonji and Card (1991), LaLonde and Topel (1991), and Goldin (1994) have tested for correlations between immigrant flows into local labor markets and local native wages.

Graphically, the area-analysis model also looks like Figure 2 -- but with the key difference that now this figure represents local, not national, conditions. Here, immigration shifts only the local relative supply of labor and thus depresses only local unskilled wages. Given this, the areaanalysis model predicts the following: unskilled (skilled) workers in gateway communities should prefer policies to lower (raise) immigration inflows. What about workers in non-gateway communities? With no geographic labor mobility over time horizons relevant to individuals when evaluating immigration policy, there should be no correlation between these workers' skills and their preferences. More generally, with some labor mobility workers in non-gateway communities should have qualitatively similar preferences but the skills-preferences link should be stronger among gateway workers. Less-skilled (more-skilled) workers in gateway communities should have stronger preferences for more-restrictionist (less-restrictionist) immigration policies than lessskilled (more-skilled) workers in non-gateway communities. 


\section{Data Description and Empirical Specification}

\subsection{Data Description}

We measure immigration-policy preferences by responses to the following question asked in the 1992 NES survey.

"Do you think the number of immigrants from foreign countries who are permitted to come to the United States to live should be increased a little, increased a lot, decreased a little, decreased a lot, or left the same as it is now?"

This question requires respondents to reveal their general position on the proper direction for U.S. immigration policy. To apply our theory framework to this question, we assume that respondents think that U.S. immigrant inflows increase the relative supply of less-skilled workers. As we discussed, this assumption clearly reflects the facts about U.S. immigration in recent decades. We constructed the variable Immigration Opinion by coding responses 5 for those individuals responding "decreased a lot" down to 1 for those responding "increased a lot." Thus, higher levels of Immigration Opinion indicate preferences for more-restrictive policy. ${ }^{10}$

Our theoretical framework hypothesizes that immigration policy can affect individuals' factor income according to their skill levels. To test whether skills are a key determinant of immigrationpolicy preferences, for each individual we construct two commonly used skill measures. First, respondents were asked to report their occupations coded according to the three-digit 1980 Census Occupation Code classification. From the U.S. Department of Labor (1992) we obtained the 1992 U.S. average weekly wage for each three-digit occupation. Under the assumption that the average market returns for a given occupation are determined primarily by the skills required for that occupation, these average wages, called Occupational Wage, measure respondents' skill levels. As a second skill measure, the NES survey also records the years of education completed by each respondent, Education Years. Educational attainment is another commonly used measure of skills, so we use it as an alternative skills variable.

\footnotetext{
${ }^{10}$ The 1992 NES survey asked other questions about immigration-related topics which we do not analyze. For example, respondents were asked whether they think Asians or Hispanics "take jobs away from people already here". We do not focus on this question because it does not explicitly address immigration policy. Moreover, its responses cannot clearly distinguish among our three competing economic models. All our models assume full employment, so no natives could have jobs permanently "taken away" from immigrants. Moreover, our models are silent on the dynamics of adjustment. All three models could have immigrants "taking" jobs from natives during adjustment to a new full-employment equilibrium.
} 
As discussed earlier, Citrin, et al (1997) interpret educational attainment as a demographic variable rather than a skills variable. Below we present strong evidence that education measures labor-market skills once other considerations such as gender and political ideology are controlled for. Also, our mapping of occupation categories into average occupation wages captures skills across occupations much more accurately than the poorly defined occupation categorical variables in Citrin, et al (1997).

In addition to skill measures, we need measures of where respondents live combined with information about gateway communities. For each respondent the NES reports the county, state, and (where appropriate) metropolitan statistical area (MSA) of residence. We combine this information with immigration data to construct several alternative measures of residence in a highimmigration area. First, we defined local labor markets two ways: by a combination of MSAs and counties, and by states. In our MSA/county definition each MSA (with all its constituent cities and counties) is a separate labor market; for individuals living outside an MSA the labor market is the county of residence. Following the extensive use of MSAs in area-analysis studies and Bartel's (1989) finding that immigrants arrive mostly into cities, we prefer the MSA/county definition but try states for robustness. Second, for each definition of local labor markets we try three different definitions of a high-immigration labor market: 5\%, 10\%, and 20\% shares of immigrants in the local population. These immigration and labor-force data are from the 1990 decennial census as reported by the U.S. Bureau of the Census (1994). Altogether, for each of our six primary measures we construct a dichotomous variable, High Immigration MSA, equal to one for residents in high-immigration labor markets. In the tables we report results for our preferred measure, the MSA/county - $10 \%$ definition. Alternative measures are discussed in the robustness checks. ${ }^{11}$

We also constructed several measures of non-economic determinants of preferences. Following previous work in the political-economy literature, we include the following measures in our baseline analysis: gender; age; race; ethnicity; personal immigrant status; party identification;

\footnotetext{
${ }^{11}$ In 1990 immigrants accounted for 7.9\% of the overall U.S. population. Accordingly, our 5\% cutoff might seem too low, but for completeness we tried it anyway. Also, the 1990 Census MSA data are organized by 1990 MSA definitions, but the 1992 NES survey locates individuals by 1980 MSA definitions. Using unpublished information on 1980-1990 MSA changes obtained from Census officials, we corrected discrepancies as best we could.
} 
and political ideology. Gender is a dichotomous variable equal to one for females. Age is a continuous variable. For race we construct the dichotomous variable Black, equal to one if the respondent is African-American. For ethnicity we construct the dichotomous variable Hispanic, equal to one if the individual self-identifies with a Hispanic ethnic group. Immigrant is a dichotomous variable equal to one if the respondent or his/her parents were immigrants into the United States. Party Identification is a categorical variable ranging from one for "strong Democrat" to seven for "strong Republican." Finally, Ideology is a categorical variable ranging from one for "extremely liberal" to seven for "extremely conservative." In addition to these variables, for certain specifications we included additional regressors which we discuss below in the robustness checks.

\subsection{Missing Data and Multiple Imputation}

Upon constructing the variables described in Section 4.1 and combining them into one individual-level data set, we observed that there was a significant amount of missing data. In the NES survey some individuals did not report either occupation or educational attainment; for these respondents we could not construct skill measures. Missing data also existed for some of our noneconomic determinants of immigration-policy preferences. Across the range of models which we estimated, when we simply dropped observations with any missing data we generally lost between $40 \%$ and $45 \%$ of the total observations.

This standard approach for dealing with missing values, known as "listwise deletion," can create two major problems. One is inefficiency caused by throwing away information relevant to the statistical inferences being made. Furthermore, inferences from listwise-deletion estimation can be biased if the observed data differs systematically from the unobserved data. In our case inefficiency was clearly a problem. We also had little reason to think our data were missing at random, so we worried about biased inferences (see King, et al (1998a) for a detailed discussion).

Alternatives to listwise-deletion for dealing with missing data have been developed in recent years. The most general and extensively researched approach is "multiple imputation" (King, et al (1998a), Schafer (1997), Little and Rubin (1987), Rubin (1987)). Multiple imputation makes a much weaker assumption than list-wise deletion about the process generating the missing data. 
Rather than assuming that the unobserved data is missing completely at random, multiple imputation is consistent and gives correct uncertainty estimates if the data are missing randomly conditional on the data included in the imputation procedures. The approach has several variations but always involves three main steps. First, some algorithm is used to impute values for the missing data. In this step, $m(m>1)$ "complete" data sets are created consisting of all the observed data and imputations for the missing values. The second step simply involves analyzing each of the $m$ data sets using standard complete-data statistical methods. The final step combines the parameter estimates and variances from the $m$ complete-data analyses to form a single set of parameter estimates and variances. Importantly, this step systematically accounts for variation across the $m$ analyses due to missing data in addition to ordinary sample variation.

The first step in our multiple-imputation procedures was to create imputations in the missing data cells for all the variables discussed in Section 4.1. We based our imputations on 29 variables selected from the NES survey. These variables included all those used in our analysis as well as additional information from the survey which we determined would be helpful in predicting the missing data. Altogether we imputed 10 complete individual-level data sets. ${ }^{12}$ The exact imputation algorithm we used is known by the acronym "EMis" because to generate imputations it combines a well-known Expectation Maximization missing data algorithm with a round of importance sampling. King et al (1998a) provide a complete explanation of the use of this algorithm for missing data problems. Each of our 10 final data sets contains 2485 observations, equal to the actual number of individuals in the NES survey. Also, each data set contains the exact same non-imputed information--they differ only in their imputed values for missing data.

The second step in our multiple-imputation analysis was to run various ordered probit models separately on each of the 10 final data sets. The last multiple-imputation step was to combine the 10 sets of estimation results to obtain a single set of estimated parameter means and variances. The single set of estimated means is simply the arithmetic average of the 10 different estimation results. The single set of estimated variances is more complicated than a simple average because, as

\footnotetext{
12 The imputation procedures were implemented using Amelia: A Program for Missing Data (Honaker, et al 1998).
} 
mentioned above, these variances account for both the ordinary within-sample variation and the between-sample variation due to missing data. See King et al (1998a) and Schafer (1997) for a complete description of these variances.

Table 1 reports the summary statistics of our immigration-opinion measure and explanatory variables calculated by pooling together all 10 of the imputed data sets. The "average" value for Immigration Opinion was about 3.6, between the responses "left the same as it is now" and "decreased a little." Also, 23.5\% of respondents lived in an MSA/county with an immigrant concentration of at least $10 \% .{ }^{13}$

\subsection{Econometric Model}

Our empirical work aims to test how skills and other factors affect the probability that an individual supports a certain level of legal immigration. The level of immigration preferred by a respondent could theoretically take on any value, but we do not observe this level. We observe only whether or not the respondent chose one of five ordered categories. Because we have no strong reason to think ex ante that these five ordered categories are separated by equal intervals, a linear regression model might produce biased estimates. The more appropriate model for this situation is an ordered probit which estimates not only a set of effect parameters but also an additional set of parameters representing the unobserved thresholds between categories.

In all our specifications we estimate an ordered probit model where the expected mean of the unobserved preferred immigration level is hypothesized to be a linear function of the respondent's skills, a vector of demographic identifiers, political orientation, and (perhaps) the immigration concentration in the respondent's community. The key hypothesis we want to evaluate is whether more-skilled individuals are less likely to support restrictionist immigration policies as predicted in

\footnotetext{
${ }^{13}$ The exact breakdown of all responses to Immigration Opinion is as follows: 58 "increased a lot" (2.3\% of the total sample, 2485); 116 "increased a little" (4.7\%); 937 "left the same" (37.7\%); 552 "decreased a little" (22.2\%); and 505 "decreased a lot" (20.3\%). In addition we imputed responses for the 87 people (3.5\%) responding "don't know / no answer" and the 230 people (9.3\%) not asked the question because of survey design (all results reported in the paper are robust to excluding these 230 observations from the analysis). Among our other High Immigration Area measures, 43.7\% of respondents lived in MSA/county with immigrants accounting for at least $5 \%$ of the population, while $8.5 \%$ of respondents lived in an MSA/county with immigrants accounting for at least $20 \%$ of the population. Finally, we note that the summary statistics in our data are similar to those obtained from the 1992 Merged Outgoing Rotation Groups of the Current Population Survey (CPS). For example, in the 1992 CPS $52.2 \%$ of the sample was female, $11.5 \%$ was black, and the average age was 43.3.
} 
the multi-cone Heckscher Ohlin trade model and in the factor-proportions-analysis model. Accordingly, in our baseline specifications we regress stated immigration-policy preferences on skills, demographic identifiers, and political orientation. In a second set of specifications we also include a dummy variable indicating whether or not the respondent lives in a high-immigration area and an interaction term between this indicator and the respondent's skills. With these second specifications we can test whether the skills-immigration correlation is strongest in highimmigration labor markets as predicted in the area-analysis model.

\section{Empirical Results}

\subsection{Testing How Skills Affect Immigration-Policy Preferences}

Our initial specifications, estimated on the entire sample, allow us to test the HO and factorproportions-analysis models. Table 2 presents the results, where in Model 1 we measure skills with Occupational Wage and in Model 2 we use Education Years. The key message of Table 2 is that by either measure, skill levels are significantly correlated with Immigration Opinion at at least the $99 \%$ level. Less-skilled (more-skilled) people prefer more-restrictionist (less-restrictionist) immigration policy. This skills-preferences link holds conditional on a large set of plausible noneconomic determinants of Immigration Opinion. Among these other regressors Gender, Age, Hispanic, and Party Identification are insignificantly different from zero. Black and Immigrant are significantly negative: blacks, and the group of immigrants plus children of immigrants, prefer less-restrictionist immigration policy. Ideology is significantly positive: more-conservative people prefer more-restrictionist immigration policy. We note that these non-skill estimates are similar to those found by Citrin, et al (1997) and Espenshade and Hempstead (1995). ${ }^{14}$

The actual coefficient estimates in Table 2 identify the qualitative effect on ImmigrationOpinion of skills and our other regressors. However, these coefficients do not answer our key substantive question of how changes in skill levels affect the probability that an individual supports immigration restrictions. To answer this question we used the estimates of Models 1 and 2 to

\footnotetext{
${ }^{14}$ Appendix Table A1 reports results for the Table 2 specifications estimated on the listwise-deletion data set. The qualitative results are similar to those discussed in the paper using multiple imputation. However, using conventional rules for inference, the statistical significance of the effects of several control variables differs across the two methodologies.
} 
conduct simulations calculating the effect on immigration preferences of changing skills while holding the other variables constant at their sample means.

Our simulation procedure works as follows. Recognizing that the parameters are estimated with uncertainty, we drew 1000 simulated sets of parameters from their sampling distribution defined as a multivariate normal distribution with mean equal to the maximum likelihood parameter estimates and variance equal to the variance-covariance matrix of these estimates. For each of the 1000 simulated sets of coefficients we then calculated two probabilities. Setting all variables equal to their sample means, we first calculated the estimated probability of supporting immigration restrictions, i.e., the probability of supporting a reduction in immigration by either "a lot" or "a little." We then calculated the estimated probability of supporting immigration restrictions when our skills measure is increased to its sample maximum while holding fixed all other regressors at their means. The difference between these two estimated probabilities is the estimated difference in the probability of supporting immigration restrictions between an individual with average skills and someone with "maximum" skills. We calculated this difference 1000 times, and then to show the distribution of this difference we calculated its mean, its standard error, and a $90 \%$ confidence interval around the mean.

Table 3 reports the results of this simulation for our two models. Increasing Occupational Wage from its mean to its maximum ( $\$ 513$ per week to $\$ 1138$ per week), holding fixed all other regressors at their means, reduces the probability of supporting immigration restrictions by 0.086 on average. This estimated change has a standard error of 0.031 and a $90 \%$ confidence interval of $(-0.138,-0.036)$. The results for Education Years are similar. Increasing Education Years from its mean to its maximum (about 12.9 years to 17 years), holding fixed all other regressors at their means, reduces the probability of supporting immigration restrictions by 0.126 on average. This estimated change has a standard error of 0.029 and a $90 \%$ confidence interval of $(-0.174,-0.081)$. Both cases give the same result: higher skills are strongly and significantly correlated with lower probabilities of supporting immigration restrictions. 15

\footnotetext{
${ }^{15}$ For our simulation procedures we used the Stata program CLARIFY (Tomz, et al 1998). These procedures are discussed in King, et al (1998b).
} 
Citrin, et al (1997) assume that Occupational Wage and Education Years do not measure labormarket skills. For example, Education Years might indicate tolerance or civic awareness. To test this possibility, we split our sample between those in the labor force and those not in the labor force and then reestimated Models 1 and 2 on each subsample. If OccupationWage and Education Years measure labor-market skills, then the correlation between these regressors and Immigration Opinion should hold only among labor-force participants. If these regressors measure non-labormarket considerations, then their explanatory power should not vary across the two subsamples. Table 4 reports the results. For the labor-force subsample both OccupationWage and Education Years are strongly significant -- in fact, these coefficient estimates are larger than the full-sample estimates from Table 2. For the not-in-labor-force subsample the coefficient estimates are much smaller (in absolute value) and are not significant. We interpret these results as strong evidence that Occupation Wage and Education Years measure labor-market skills. ${ }^{16}$

The result that skills correlate with immigration-policy preferences is inconsistent with an $\mathrm{HO}$ model in which immigration is completely absorbed by Rybczynski output-mix effects. It is consistent both with the factor-proportions-analysis model and with an HO model in which immigration affects both wages and output mix. By pooling all regions of the country in Tables 2 through 4, however, we have not yet tested the area-analysis model. To do this we modify our initial specifications by adding the regressor High Immigration MSA and its interaction with skills. If preferences are consistent with the area-analysis model, then less-skilled (more-skilled) workers in gateway communities should have stronger preferences for more-restrictionist (lessrestrictionist) immigration policies than less-skilled (more-skilled) workers in non-gateway communities. These preferences imply a positive coefficient on High Immigration MSA and a negative coefficient on its interaction with skills. ${ }^{17}$

\footnotetext{
${ }^{16} \mathrm{We}$ defined the subset of labor-force participants as those individuals reporting they were either employed or "temporarily" unemployed but seeking work. This subsample is $64.9 \%$ of the total sample, close to the 1992 aggregate labor-force participation rate of $66.6 \%$. The reported occupation for those not in the labor force is their most-recent job. Also, we obtained the same results qualitatively from an alternative specification of our skills test in which we pooled the full sample and interacted skills with a dichotomous variable for labor-force status participation. The split-sample test is more general in that it does not constrain the non-skill regressors to have the same coefficient for both labor-force groups.

${ }^{17}$ The positive coefficient on High Immigration MSA would indicate that low-skilled people in high-immigration areas prefer more-restrictive policies relative to low-skilled people living elsewhere. Combined with this positive coefficient,
} 
Table 5 presents the results for this specification, where Model 3 uses OccupationalWage and Model 4 Education Years. The results for all the non-skill regressors are qualitatively the same as before. Our skill measures are still negatively correlated with preferences at at least the $95 \%$ level. But in neither case is High Immigration MSA significantly positive or its interaction with skills significantly negative. In fact, for Education Years we obtain the exact opposite coefficients on both regressors at about the $95 \%$ significance level. In unreported specifications we tested this specification using our other five definitions of High Immigration MSA and/or splitting the sample as in Table 4. In almost every case the interaction term's coefficient was positive but not significant; in no case did the interaction term ever have a significantly negative coefficient or High Immigration MSA a significantly positive one. Overall, people living in high-immigration areas do not have a stronger correlation between skills and immigration-policy preferences than people living elsewhere. If anything, the skills-preferences link may be attenuated in high-immigration areas. In any case, we conclude that this link is inconsistent with the area-analysis model. ${ }^{18}$

\subsection{Robustness Checks}

We checked the robustness of the empirical results by trying other measures of our important regressors. For skills we tried three dichotomous variables of educational attainment (high-school dropouts, high-school graduates, and some college--the omitted group being college and beyond) to look for any non-linearities in how skills affect preferences. ${ }^{19}$ We discovered no clear nonlinearities: the relative coefficients on the dichotomous measures seemed consistent with an overall linear effect. For skills we also tried the respondents' reported 1991 annual income, and obtained

the negative interaction term would indicate that high-skilled people in high-immigration areas prefer less-restrictive policies relative to high-skilled people living elsewhere.

18 Although the attenuation was only marginally significant in a few regressions, we explored further what might cause it. One possibility is that more-skilled people in gateway communities worry about higher tax liabilities caused by an immigration-induced rise in demand for public services. If this were true, the skills regressor would be conflating two separate effects: the wage effect and the tax effect. To test this hypothesis we added "fiscal" regressors (home ownership; annual family income; and individual responses to the question of whether immigrants "cause higher taxes due to more demands for more public services") to our specification to control for individual tax liability. If the tax hypothesis were true then the skills-preferences attenuation would disappear in specifications which include the fiscal regressors. This did not happen, however. An alternative explanation is that people in high-immigration communities worry less about wage effects than people elsewhere because they have more direct experience of the output-mix effects of the HO model. Unfortunately, we know of no good way to test this idea in our data.

${ }^{19}$ Among those answering the Education Years question there were 466 high-school drop-outs, 812 high-school graduates, 572 people with some college, and 570 people with a college degree or higher. 
qualitatively similar results to those for Occupation Wage and Education Years. ${ }^{20}$ In addition to the six measures of High Immigration Area discussed earlier, we also tried a dichotomous measure of residence in one of the "big six" immigrant states of California, Florida, Illinois, New Jersey, New York, and Texas. Borjas, et al (1997) report that in 1960 60\% of all U.S. immigrants lived in these six states and that by 1990 that share had risen to 75\%. Borjas, et al (1996) report that in $199260 \%$ of all U.S. legal immigrants came into California or New York alone; another 20\% entered the other four gateway states. With this measure we again found no evidence of preferences consistent with the area-analysis model.

We also checked the robustness of our results by including other regressors. One was union membership: union members preferred more-restrictionist immigration policy, an effect that was statistically significant in some specifications. Two other regressors were retrospectiveevaluations of the national economy and retrospective evaluations of personal finances. Both retrospective measures tended to have the expected sign -- those with gloomier retrospections preferred morerestrictionist immigration policy -- but were always insignificant. Finally, we included state unemployment rates, another geography-varying regressor in addition to High Immigration MSA, to control in the cross-section for any business-cycle effect on immigration-policy preferences. This regressor was always insignificant, however.

\section{Conclusion}

In this paper we have provided new evidence on the determinants of individual immigrationpolicy preferences and on what these preferences imply about how economies absorb immigrants. In particular, we documented a robust link between labor-market skills and preferences: lessskilled (more-skilled) people prefer more-restrictionist (less-restrictionist) immigration policy. This link strongly supports the contention that people's position in the labor force influences their policy opinions. It is consistent both with the factor-proportions-analysis model and with a Heckscher-Ohlin multi-cone model. We found no evidence that this skills-preferences link is

\footnotetext{
${ }^{20}$ Despite this similarity, we regard average occupation wages and education to be superior skill measures. These two variables probably better reflect an individual's long-run earnings capacity; in contrast, annual income can fluctuate more for reasons unrelated to skill (such as illnesses, inheritances, or overtime).
} 
stronger in high-immigration labor markets--if anything, the link may be attenuated in these areas. This finding is inconsistent with the area-analysis model.

These results are important for constructing empirically useful models of the political economy of immigration policymaking in receiving states. In particular, the link between skills and immigration-policy preferences suggests the potential for immigration politics to be connected to the mainstream redistributive politics over which political parties often contest elections. In addition, our findings shed further light both on how individuals form preferences over international economic policies and what these preferences imply for the domestic politics of countries with significant flows of goods, capital, and people across their borders. The skills cleavage over immigration policy reinforces our earlier finding of a strong relationship between individual skill levels and support for trade protection in the United States (Scheve and Slaughter, 1998). Taken together, these two studies suggest that skill levels play an important role in shaping political divisions in the electorate over international economic policies. 


\section{References}

Altonji, Joseph, and David Card. 1991. "The Effects of Immigration on the Labor Market Outcomes of Less-Skilled Natives." In John Abowd and Richard Freeman, eds, Immigration, Trade, and the Labor Market, (Chicago, IL: University of Chicago Press), 201-234.

Bartel, Ann. 1989. "Where Do the New U.S. Immigrants Live?" Journal of Labor Economics 7 (4): 371-391.

Benhabib, Jess. 1996. "On the Political Economy of Immigration." European Economic Review 40: 1737-1743.

Berman, Eli, John Bound, and Zvi Griliches. 1994. "Changes in the Demand for Skilled Labor within U.S. Manufacturing: Evidence from the Annual Survey of Manufactures." Quarterly Journal of Economics: 367-397.

Bilal, Sanoussi, Jean-Marie Grether, and Jamie de Melo. 1998. "Determinants of Attitudes Towards Immigration: A Trade-Theoretic Approach." Center for Economic Policy Research Discussion Paper No. 1877.

Borjas, George J. 1994. "The Economics of Immigration." Journal of Economic Literature 32: 1667-1717.

Borjas, George J. 1995. "The Economic Benefits From Immigration." Journal of Economic Perspectives 9 (2): 3-22.

Borjas, George J., Richard B. Freeman, and Lawrence F. Katz. 1996. "Searching for the Effect of Immigration on the Labor Market." American Economic Review 86 (2): 247-251.

Borjas, George J., Richard B. Freeman, and Lawrence F. Katz. 1997. "How Much Do Immigration and Trade Affect Labor Market Outcomes?" Brookings Papers on Economic Activity 1: $1-90$.

Butcher, Kristin F. and David Card. 1991. "Immigration and Wages: Evidence from the 1980's." American Economic Review 81 (2): 292-296.

Card, David. 1990. "The Impact of the Mariel Boatlift on the Miami Labor Market." Industrialand Labor Relations Review 43 (2): 245-257.

Citrin, Jack, Donald Green, Christopher Muste, and Cara Wong. 1997. "Public Opinion Toward Immigration Reform: The Role of Economic Motivation." The Journal of Politics 59 (3): 858-81.

Espenshade, Thomas J. and Katherine Hempstead. 1996. "Contemporary American Attitudes Toward U.S. Immigration." International Migration Review 30 (2): 535-570.

Freeman, Gary. 1992. "Migration Policy and Politics in the Receiving States." International Migration Review 26 (4): 1144-1167.

Freeman, Gary P. 1995. "Modes of Immigration Politics in Liberal Democratic States." International Migration Review 29 (4): 881-902. 
Friedberg, Rachel, and Jennifer Hunt. 1995. "The Impact of Immigrants on Host Country Wages, Employment, and Growth." Journal of Economic Perspectives 9 (2): 23-44.

Hanson, Gordon H., and Matthew J. Slaughter. 1999. "Factor-Price Insensitivity to Immigration and the Rybczynski Theorem: Evidence From U.S. States." Mimeograph.

Hanson, Gordon H., and Antonio Spilimbergo. Forthcoming 1998. "Illegal Immigration, Border Enforcement, and Relative Wages: Evidence from Apprehensions at the U.S.-Mexico Border." American Economic Review.

Honaker, James, Anne Joseph, Gary King, and Kenneth Scheve. 1998. Amelia: A Program for Missing Data. Version 0.9. Cambridge, MA: Harvard University.

Goldin, Claudia. 1994. "The Political Economy of Immigration Restriction in the United States, 1890 to 1921." In Claudia Goldin and Gary Libecap, eds, The Regulated Economy: A Historical Approach to Political Economy (Chicago, IL: University of Chicago Press), 223-257.

Joppke, L. 1998. "Why Liberal States Accept Unwanted Immigration." World Politics 50: 266293.

Katz, Lawrence F. and Kevin M. Murphy. 1992. "Changes in Relative Wages, 1963-1987: Supply and Demand Factors." Quarterly Journal of Economics: 35-78.

Kessler, Alan. 1998. "Distributional Coalitions, Trade, and the Politics of Postwar American Immigration." Paper prepared for delivery at the 1998 Annual Meeting of the American Political Science Association, Boston, MA.

King, Gary, James Honaker, Anne Joseph, and Kenneth Scheve. 1998a. "Listwise Deletion is Evil: What to Do About Missing Data in Political Science." Paper prepared for the presentation at the Annual Meetings of the American Political Science Association, Boston, MA.

King, Gary, Michael Tomz, and Jason Wittenberg. 1998b. "Making the Most of Statistical Analyses: Improving Interpretation and Presentation." Paper prepared for presentation at the Annual Meetings of the American Political Science Association, Boston, MA.

LaLonde, Robert and Robert Topel. 1991. "Labor Market Adjustments to Increased Immigration." In John Abowd and Richard Freeman, eds, Immigration, Trade, and the Labor Market, (Chicago, IL: University of Chicago Press), 167-200.

Lawrence, Robert Z. and Matthew J. Slaughter. 1993. "International Trade and American Wages in the 1980s: Giant Sucking Sound or Small Hiccup?" in Martin Neil Baily and Clifford Winston (eds) Brookings Papers on Economic Activity: Microeconomics 2: 161-211.

Leamer, Edward E., and James Levinsohn. 1995. "International Trade Theory: The Evidence." Handbook on International Economics, Volume 3.

Little, Roderick J. A., and Donald B. Rubin, Statistical Analysis with Missing Data, New York: J. Wiley \& Sons, 1987.

Miller, Warren E., Donald R. Kinder, Steven J. Rosenstone, and the National Election Studies. 1993. American National Election Study, 1992: Pre-and Post-Election Survey (Enhanced With 1990 and 1991 Data) [Computer file]. Conducted by University of Michigan, Center for Political Studies. ICPSR ed. Ann Arbor, MI: University of Michigan, Center for Political Studies, and 
Inter-University Consortium for Political and Social Research [producers]. Ann Arbor, MI: InterUniversity Consortium for Political and Social Research [distributor].

Money, Jeannette. 1997. "No Vacancy, The Political Geography of Immigration Control in Advanced Industrial Democracies." International Organization 51: 685-720.

Perotti, Rosanna. 1998. "Entrepreneurial Politics and the 1996 Immigration Reforms." Paper prepared for delivery at the 1998 Annual Meeting of the American Political Science Association, Boston, MA.

Rubin, Donald B. 1987. Multiple Imputation for Nonresponse in Surveys, New York: J. Wiley \& Sons.

Samuelson, Paul. 1948. "International Trade and the Equalization of Factor Prices." Economic Journal 48: 163-184.

Schafer, Joseph L. 1997. Analysis of Incomplete Multivariate Data, London: Chapman \& Hall.

Scheve, Kenneth F., and Matthew J. Slaughter. 1998. "What Determines Individual Trade-Policy Preferences." National Bureau of Economic Research Working Paper No. 6531.

Simon, Rita, and Susan Alexander. 1993. The Ambivalent Welcome: Print Media, Public Opinion, and Immigration. Westport, CT: Praeger.

Timmer, Ashley, and Jeffrey Williamson. 1996. "Racism, Xenophobia or Markets? The Political Economy of Immigration Policy Prior to the Thirties." National Bureau of Economic Research Working Paper No. 5867.

Tomz, Michael, Jason Wittenberg, and Gary King (1998). CLARIFY: Software for Interpreting and Presenting Statistical Results. Version 1.2. Cambridge, MA: Harvard University, September 16. Available at http://gking.harvard.edu/.

United States Bureau of the Census. 1994. 1994 State and Metropolitan Area Data Book. Washington, D.C.: U.S. Government Printing Office.

United States Department of Labor, Bureau of Labor Statistics. 1992. Unpublished Tabulations From the Current Population Survey, 1992 Annual Averages. 
Figure 1

Labor-Market Equilibrium:

The Heckscher-Ohlin Model

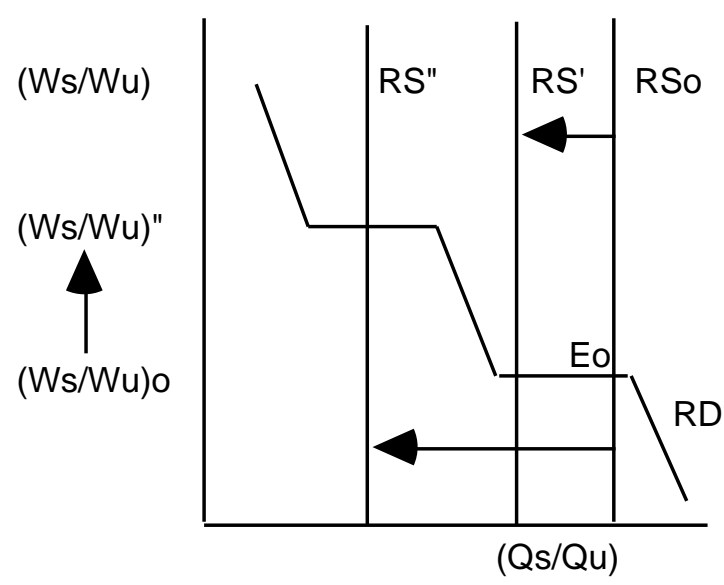

Notes: Skilled labor is subscripted "s" and unskilled labor "u". The $\mathrm{RS}$ schedule is national relative supply and the RD schedule is national relative demand.

Figure 2

Labor-Market Equilibrium:

The Factor-Proportions-Analysis Model or

The Area-Analysis Model

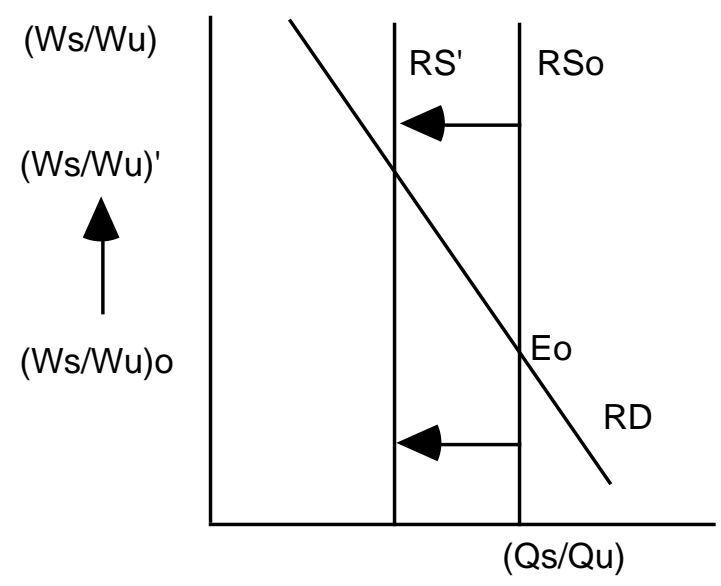

Notes: Skilled labor is subscripted "s" and unskilled labor "u". The RS schedule is relative supply and the RD schedule is relative demand. For the factor-proportions-analysis model this picture represents the single national labor market; for the area-analysis model this picture represents each separate local labor market. 


\section{Table 1 \\ Summary Statistics}

\begin{tabular}{ccc}
\hline \hline Variable & Mean & Standard Deviation \\
\hline Immigration Opinion & 3.595 & 1.027 \\
Occupational Wage & 0.512 & 0.187 \\
Education Years & 12.923 & 2.815 \\
Gender & 0.534 & 0.499 \\
Age & 45.755 & 17.711 \\
Black & 0.129 & 0.336 \\
Hispanic & 0.072 & 0.259 \\
Immigrant & 0.181 & 0.385 \\
Party ID & 3.701 & 2.027 \\
Ideology & 4.237 & 1.399 \\
High Immigration MSA & 0.235 & 0.424 \\
\hline
\end{tabular}

Notes: These summary statistics are multiple imputation estimates based on the 10 imputed data sets with 2485 observations for each variable in each data set. The variable Occupational Wage reports the actual weekly wage divided by 1000. 
Table 2

Determinants of Immigration-Policy Preferences:

Testing the Heckscher-Ohlin and Factor-Proportions-Analysis Models

\begin{tabular}{|c|c|c|c|c|c|c|}
\hline \multirow[b]{2}{*}{ Regressor } & \multicolumn{3}{|c|}{ Model 1} & \multicolumn{3}{|c|}{ Model 2} \\
\hline & Coefficient & Std. Error & P-Value & Coefficient & Std. Error & P-Value \\
\hline Occupational Wage & -0.349 & 0.130 & 0.007 & & & \\
\hline Education Years & & & & -0.044 & 0.010 & 0.000 \\
\hline Gender & -0.022 & 0.048 & 0.655 & -0.008 & 0.046 & 0.866 \\
\hline Age & -0.000 & 0.001 & 0.988 & -0.002 & 0.001 & 0.181 \\
\hline Black & -0.207 & 0.080 & 0.010 & -0.225 & 0.080 & 0.005 \\
\hline Hispanic & -0.064 & 0.111 & 0.566 & -0.122 & 0.110 & 0.268 \\
\hline Immigrant & -0.158 & 0.066 & 0.017 & -0.150 & 0.066 & 0.022 \\
\hline Party ID & 0.003 & 0.013 & 0.826 & 0.008 & 0.013 & 0.530 \\
\hline Ideology & 0.057 & 0.020 & 0.005 & 0.050 & 0.020 & 0.013 \\
\hline Tau 1 & -1.849 & 0.138 & 0.000 & -2.345 & 0.185 & 0.000 \\
\hline Tau 2 & -1.288 & 0.129 & 0.000 & -1.782 & 0.179 & 0.000 \\
\hline Tau 3 & 0.024 & 0.127 & 0.853 & -0.464 & 0.175 & 0.008 \\
\hline Tau 4 & 0.724 & 0.131 & 0.000 & 0.240 & 0.175 & 0.169 \\
\hline
\end{tabular}

Notes: These results are multiple-imputation estimates of ordered-probit coefficients based on the 10 imputed data sets with 2485 observations in each data set. In both models the dependent variable is individual opinions about whether U.S. policy should increase, decrease, or keep the same the annual number of legal immigrants. This variable is defined such that higher (lower) values indicate more-restrictive (less-restrictive) policy preferences. The regressors Tau 1 through Tau 4 are the estimated cut points. 
Table 3

Estimated Effect of Increasing Skill Levels

on the Probability of Supporting Immigration Restrictions

\begin{tabular}{cc}
\hline \hline $\begin{array}{c}\text { Increase Skill Measure } \\
\text { From Mean to Maximum }\end{array}$ & $\begin{array}{c}\text { Change in Probability of Supporting } \\
\text { Immigration Restrictions }\end{array}$ \\
\cline { 1 - 2 } Occupation Wage & -0.086 \\
& $(0.031)$ \\
Education Years & {$[-0.138,-0.036]$} \\
& -0.126 \\
& $(0.029)$ \\
& {$[-0.174,-0.081]$} \\
\hline
\end{tabular}

Notes: Using the estimates from Model 1 and 2, we simulated the consequences of changing each skill measure from its mean to its maximum on the probability of supporting immigration restrictions. The mean effect is reported first, with the standard error of this estimate in parentheses followed by a $90 \%$ confidence interval.

Table 4

Differential Impact of Skill on Immigration-Policy Preferences: Labor-Force Participants and Non-Labor-Force Participants

\begin{tabular}{|c|c|c|}
\hline & \multicolumn{2}{|c|}{ Skill Measure } \\
\hline Sample & Occupation Wage & Education Years \\
\hline In Labor Force & $\begin{array}{c}-0.396 \\
(0.158)\end{array}$ & $\begin{array}{c}-0.077 \\
(0.013)\end{array}$ \\
\hline Not In Labor Force & $\begin{array}{c}-0.248 \\
(0.254)\end{array}$ & $\begin{array}{l}-0.012 \\
(0.015)\end{array}$ \\
\hline
\end{tabular}

Notes: Table displays multiple imputation estimates of ordered probit coefficients for the skill measures when the sample is limited to either respondents currently in the labor force (1613 people) or those not currently in the labor force ( 872 people). The standard error of each estimate is listed in parentheses. Each specification includes all the other control variables from Table 2. 


\section{Table 5}

Determinants of Immigration-Policy Preferences:

Testing the Area-Analysis Model

\begin{tabular}{|c|c|c|c|c|c|c|}
\hline \multirow[b]{2}{*}{ Regressor } & \multicolumn{3}{|c|}{ Model 3} & \multicolumn{3}{|c|}{ Model 4} \\
\hline & Coefficient & Std. Error & P-Value & Coefficient & Std. Error & P-Value \\
\hline Occupational Wage & -0.334 & 0.161 & 0.038 & & & \\
\hline $\begin{array}{c}\text { Occ. Wage } x \\
\text { High Imm. MSA }\end{array}$ & -0.030 & 0.309 & 0.924 & & & \\
\hline Education Years & & & & -0.054 & 0.011 & 0.000 \\
\hline $\begin{array}{c}\text { Education Years x } \\
\text { High Imm. MSA }\end{array}$ & & & & 0.038 & 0.019 & 0.048 \\
\hline High Imm. MSA & -0.005 & 0.168 & 0.977 & -0.501 & 0.264 & 0.058 \\
\hline Gender & -0.021 & 0.048 & 0.667 & -0.009 & 0.046 & 0.841 \\
\hline Age & -0.000 & 0.001 & 0.986 & -0.002 & 0.001 & 0.186 \\
\hline Black & -0.204 & 0.080 & 0.011 & -0.224 & 0.078 & 0.004 \\
\hline Hispanic & -0.057 & 0.117 & 0.628 & -0.085 & 0.115 & 0.462 \\
\hline Immigrant & -0.154 & 0.069 & 0.026 & -0.151 & 0.069 & 0.028 \\
\hline Party ID & 0.003 & 0.013 & 0.822 & 0.009 & 0.013 & 0.496 \\
\hline Ideology & 0.057 & 0.020 & 0.005 & 0.050 & 0.020 & 0.014 \\
\hline Tau 1 & -1.847 & 0.148 & 0.000 & -2.465 & 0.190 & 0.000 \\
\hline Tau 2 & -1.286 & 0.139 & 0.000 & -1.901 & 0.183 & 0.000 \\
\hline Tau 3 & 0.026 & 0.136 & 0.846 & -0.581 & 0.179 & 0.001 \\
\hline Tau 4 & 0.727 & 0.141 & 0.000 & 0.123 & 0.179 & 0.490 \\
\hline
\end{tabular}

Notes: These results are multiple-imputation estimates of ordered-probit coefficients based on the 10 imputed data sets with 2485 observations in each data set. In both models the dependent variable is individual opinions about whether U.S. policy should increase, decrease, or keep the same the annual number of legal immigrants. This variable is defined such that higher (lower) values indicate more-restrictive (less-restrictive) policy preferences. The regressors Tau 1 through Tau 4 are the estimated cut points. 
Appendix Table A1

Determinants of Immigration-Policy Preferences:

Testing the Heckscher-Ohlin and Factor-Proportions-Analysis Models, Listwise-Deletion Estimates

\begin{tabular}{|c|c|c|c|c|c|c|}
\hline \multirow[b]{2}{*}{ Regressor } & \multicolumn{3}{|c|}{ Model 1} & \multicolumn{3}{|c|}{ Model 2} \\
\hline & Coefficient & Std. Error & P-Value & Coefficient & Std. Error & P-Value \\
\hline Occupational Wage & -0.524 & 0.160 & 0.001 & & & \\
\hline Education Years & & & & -0.061 & 0.012 & 0.000 \\
\hline Gender & 0.031 & 0.060 & 0.602 & 0.015 & 0.056 & 0.794 \\
\hline Age & -0.002 & 0.002 & 0.284 & -0.003 & 0.002 & 0.119 \\
\hline Black & -0.144 & 0.101 & 0.154 & -0.137 & 0.098 & 0.160 \\
\hline Hispanic & 0.045 & 0.149 & 0.762 & 0.007 & 0.138 & 0.961 \\
\hline Immigrant & -0.120 & 0.080 & 0.131 & -0.162 & 0.078 & 0.037 \\
\hline Party ID & 0.018 & 0.016 & 0.265 & 0.026 & 0.016 & 0.099 \\
\hline Ideology & 0.074 & 0.023 & 0.002 & 0.060 & 0.023 & 0.008 \\
\hline Tau 1 & -2.014 & 0.167 & & -2.595 & 0.227 & \\
\hline Tau 2 & -1.367 & 0.159 & & -2.002 & 0.221 & \\
\hline Tau 3 & 0.031 & 0.155 & & -0.583 & 0.217 & \\
\hline Tau 4 & 0.742 & 0.156 & & 0.127 & 0.216 & \\
\hline
\end{tabular}

Notes: These results are estimates of ordered-probit coefficients based on the listwise-deletion data set. In Model 1 there are 1380 observations; in Model 21475 observations. In both models the dependent variable is individual opinions about whether U.S. policy should increase, decrease, or keep the same the annual number of legal immigrants. This variable is defined such that higher (lower) values indicate more-restrictive (lessrestrictive) policy preferences. The regressors Tau 1 through Tau 4 are the estimated cut points. 